\title{
CORRECTION
}

View Article Online

View Journal I View Issue

D) Check for updates

Cite this: J. Mater. Chem. A, 2020, 8 1481

DOI: 10.1039/c9ta90301a

rsc.li/materials-a

\section{Correction: In pursuit of catalytic cathodes for lithium-oxygen batteries}

Ali Eftekhari*a and Balaji Ramanujam ${ }^{\mathrm{b}}$

Correction for 'In pursuit of catalytic cathodes for lithium-oxygen batteries' by Ali Eftekhari et al., J. Mater. Chem. A, 2017, 5, 7710-7731.

The Royal Society of Chemistry has been notified by Ulster University that Ali Eftekhari was not authorised to use Ulster University as an affiliation. The affiliation to Ulster University has therefore been removed at the institution's request.

The Royal Society of Chemistry apologises for these errors and any consequent inconvenience to authors and readers. 